\title{
WHO ARE OUR HAIRDRESSERS? A PLEA FOR INSTITUTIONS AND ACTION
}

\author{
John W. Dienhart
}

\begin{abstract}
This 2001 Presidential Address critically examines the mission of SBE and how it can be fulfilled. I begin with Brother Leo Ryan's 1994 Presidential Address, in which he asked how the SBE mission can be accomplished given the growing number of organizations that focus on business ethics. I take up his challenge by focusing on one objective of our stated mission: To help develop ethical business organizations. I examine two ways we might promote this objective: the Moral Market Model advocated by John Boatright in his 1998 Presidential Address and the Market of Morality model advocated by Thomas Dunfee in his 1996 Presidential Address. I argue both views are limited because they focus only on market institutions. I conclude with an example of how breast cancer awareness among African-American women was increased by relying on a multi-institutional approach: organizations (beauty parlors), individuals (hairdressers, who distributed the information), personal relationships, culture, and educational and health care institutions. The question remains: Who are our hairdressers?
\end{abstract}

Tn my address this afternoon, I look back to the Presidential Addresses of Brother Leo Ryan, John Boatright, and Thomas Dunfee. I critically analyze these addresses to examine how they can help us direct SBE in the next few years. I then discuss the case of Dr. Georgia Sadler, who is on the faculty of the Department of Surgery at the University of California, San Diego. She initiated a project to improve the health of African-American women. Dr. Sadler found an unlikely, but valuable leverage point to communicate her message and change behavior. I finish by asking what we can learn from her.

Brother Leo began his 1994 Presidential Address, "Quo Vadis; Society for Business Ethics" with the following:

We are at a critical juncture in the history of the Society. We are moving ... to a future where multiple individuals, firms, groups and organizations claim business ethics as their domain, and where other issues like environmental ethics and ... global ethics have a claim on our scholarship. ${ }^{1}$ 
Here are a few of the professional groups that discuss normative issues in business and some of our relationships to them. The list has grown since Ryan's talk in 1994.

APA: Withering on the vine

APPE: Cross membership

BETS: Cross membership

EBEN: Cross membership

IABS: Cross membership and elected officials

ISBEE: Cross membership and elected officials

SIM: Jointly sponsor meetings during the Academy of Management; cross membership and elected officials

AACSB: No relationship

EOA: No relationship

As Ryan reminds us, the question "Quo vadis?" arises from a story about St. Peter. Christians were being murdered and tortured in Rome, and Peter was fleeing to save his life. Jesus appears to him and says: "Quo vadis?" or "Where are you going?" Shamed, Peter returns to Rome, where he is crucified. I did a brief search of "Quo vadis." I found that most works that use it as a title, or as a part of a title, tend to focus on the "where are you going" part. They ignore the "By the way, you will be crucified" part. Brother Leo did not ignore it. He suggested that unless we refocused our activities, organizational death was in our future.

Ryan looked to the SBE mission statement to see where we might go. He did not find an answer, but a list of eight objectives. ${ }^{2}$

\section{Mission Statement of SBE}

The Society for Business Ethics is an international association whose objectives are:

1. To promote the study of business ethics.

2. To provide a forum in which the moral, legal, empirical, and philosophical issues of business ethics may be openly discussed and analyzed.

3. To provide a means by which those interested in and concerned with business ethics may exchange ideas.

4. To promote research and scholarship through the regular publication of the journal Business Ethics Quarterly.

5. To promote the improvement of the teaching of business ethics in universities and organizations.

6. To foster a better understanding between college and university administrators and those engaged in teaching and research in the field of business ethics.

7. To help develop ethical business organizations.

8. To develop and maintain a friendly and cooperative relationship among teachers, scholars, and practitioners in the field of business and organizational ethics. 
On which of these objectives should we focus? The concepts of comparative advantage and opportunity cost have taught us that even if we can promote one of our objectives better than any other organization, we should not pursue it if doing so interferes with another objective that has more value and that we can do even better.

What we do best, in my estimation, is to provide a forum for the exchange and development of moral, legal, empirical, and philosophical ideas (Objectives 1-4). Our trump card in this area is the Business Ethics Quarterly. The academic quality of our meetings can be spectacular, as is this one, organized by Laura Hartman. Daryl Koehn has the unenviable job of organizing next year's meetings.

No matter how great our meetings are, however, all of the groups mentioned above, except for the AACSB, hold annual meetings at which the many facets of business ethics are discussed. Those interested in business ethics may find these other meetings preferable for a variety of reasons, many of which we cannot control. Our meetings are good, but there are other games in town. What differentiates us in the forum of ideas is Business Ethics Quarterly.

What about the other objectives in the mission statement? Objectives 5, 6, and 8 urge us to make educational institutions friendlier to teachers and to the teaching of business ethics. Objective 7 urges us to make business organizations more ethical. I will focus SBE's mandate to change business organizations for the better. This is the most difficult and controversial objective.

Is SBE ready to pursue the difficult, and practical objective of helping to improve the ethics of business organizations? There are at least two problems in doing so. First, SBE is not structured in a way suited to change the behavior of business organizations. Second, our theoretical and normative base is not robust enough to ground this pursuit. ${ }^{3}$ I focus on the second problem in my address.

To establish a robust theoretical and normative base for promoting ethical business organizations, we must first deal with an ideological objection-the "Who are we to say what an ethical business is?" objection. More specifically, the objection asserts that SBE has neither the moral authority to decide what is right nor the political standing (power) to implement it.

These are powerful objections. The track record of those who have forced their answer on others in the political realm is horrific-Hitler, Stalin, Pol Pot, and the list goes on. We can assess their failures in many ways. Here are three. One assessment is that they had the right answer, but they lacked courage, intelligence, or luck needed to succeed. I reject this first assessment without further argument. The second assessment is that these leaders had the wrong answer, but the quest for the right answer should go on.

The third assessment is that there is no answer, or least not one Big Answer, that explains and resolves all our problems. The early Socrates was of this ilk. In our time, Isaiah Berlin was a proponent of this idea. In his essay "The Hedgehog and the Fox," Berlin uses these animals to represent different approaches to understanding the world: the hedgehog knows one big thing (or thinks he does), but the fox knows many little things. Berlin draws out the dangers of the quest 
for Big Knowledge and the virtues and comfort of small truths. ${ }^{4}$ Our answer, the SBE answer, to who we think we are then, is that we are foxes. We don't have some big truth to push on business, but many little ones.

But there is an irony here. Even those who claim not to have the answer, like Socrates, believe they have the best method for dealing with a world in which there is no one answer. In other, words, they have the answer after all, well disguised in a cloak of publicly proclaimed, if not personally felt, humility. Socrates' pupil dreamed up the Republic, a Hedgehog approach if there ever was one. One could argue that Plato's answer was similar, in form if not content, to that offered by Socrates-there is only one right way to solve problems.

Michael Ignatieff, Berlin's friend and biographer, makes a good a case that Berlin was a hedgehog in fox's clothing. Berlin, after all, insisted on the superiority of acknowledging the value of many small answers. The question Berlin could not fully resolve was: How do you fit those small answers into a social system that allows them to flourish? Berlin's answer was representative democracy. But representative democracy does not prevent those who hold more popular truths from marginalizing and oppressing those who hold less popular truths.

It seems that no matter how fox-like we try to become, we have the souls of hedgehogs. I turn now to the addresses by Boatright and Dunfee to see if we can escape this zoological paradox.

In his presidential address, John Boatright asks "Does Business Ethics Rest on a Mistake?"5 If it does, we should disband. Boatright does not reach this conclusion, however. He offers us a better, more accurate picture of the domain of business ethics. Instead of trying to make organizations moral, we should focus on making markets moral. Moral markets, in turn, would enforce moral discipline on organizations. Of course, this only pushes the "Who are we to say?" question back a level. Instead of having to justify our ideas about how to change organizations, we need to justify our ideas about how to change markets. While these ideas will be different, their justification should be just as difficult, if not harder. Markets are usually more pervasive than organizations. But Boatright raises some intriguing questions, and I want to delve into them.

In good Aristotelian fashion, I will argue that Boatright is right and wrong about the need to focus on markets, but not in the same sense. In this section I discuss some problems with his views. I will attend to his valuable insights in my conclusion. (Please note that my exegesis of Boatright's address is pegged to the solfeggio diatonic scale: do, re, mi, fa, so, la, ti, and do.)

Boatright argues that are two models of business ethics.

The Moral Manager Model (MgM, pronounced "midg-um")

Harvard Business School, Eastern decadence, controlling, central planning, arrogant 
The Moral Market Model (MkM, pronounced "make-um")

University of Chicago Economics Department, broad-shouldered view of the real world, market magic, invisible hand, the incredible lightness of being

In $\mathrm{MgM}$, managers are free to include ethical factors, such as care and fairness, along with maximizing profit, increasing market share, etc. This is problematic, claims Boatright. Even when managers use this freedom in the best ways, the results can be bad for the group. Suppose several people are working individually on squares for a quilt. If one person decides to modify a pattern for a square because it will look better, the resulting whole will suffer. Or, think of broken plays in football. Players deviate from their assignments because they believe doing so will make the play more successful. Such deviations almost always fail. There is a further problem with $\mathrm{MgM}$. Greedy and selfish managers can use the moral free space of $\mathrm{MgM}$ to cover self-dealing and downright destructive behavior to get more do. Boatright has made this point elsewhere. MgM hangs us on the horns of a dilemma: Whether managers are good are bad, MgM fails.

Boatright argues for $\mathrm{MkM}$, where strict business roles tightly define what managers can do. This, he argues, is better for the group, as long as the roles are designed correctly. MkM will shine the re of ethical light on business. What about $m i$, you say? You pursue your interests by choosing the right role.

How $f a$ can strict role following get us? As I interpret Boatright's address, $\mathrm{MkM}$ is better than MgM because relationships like friendship, bonds of loyalty, and preferences for things like fairness are simply not appropriate for the institutional role of business: wealth creation. But there is another non-role factor that can interfere with the business role of wealth creation: self-interest. If we follow Boatright's argument back to its core, self-interest has no role in business either.

Self-interest, one might reply, is something we cannot eliminate. Recognizing the stickiness of self-interest, efficient organizations try to align employee self-interest with corporate roles designed to create wealth. But, I would argue, we also cannot eliminate care, loyalty, or a preference for fairness. Social psychologists have generated plenty of support for the ineliminability of friendship, loyalty, and fairness. I do not want to recite the literature here. Still, it might be helpful, for the sake of illustration, if we look at how care, friendship, and their opposites can arise in business. I appeal only to our common experience as adult human beings.

I think most of would agree that we cannot interact with others on a daily basis and remain emotionally neutral toward them. Perhaps in self-defense, many of us find ways to like those with whom we work. Maybe this is a benign form of the Stockholm syndrome. If we fail to like those with whom we interact daily, we tend to dislike them. Sometimes, we loathe them. I have never seen anyone who could remain emotionally neutral with daily intimates, although I am told sociopaths can do this. Perhaps this is a reductio of the MkM view; only those with severe personality defects could people such a system. Of course, the good 
news, or bad news, is that MkM would provide new job opportunities for those who might otherwise become lawyers.

\section{A Digression}

The connection between MkM and lawyering is intriguing. It strikes me that lawyers, at least the archetypal awful ones, come closest to doing what Boatright suggests managers should do: they act within narrowly defined roles no matter how despicable the results. They must do this, they argue, if the system is to achieve justice. Why do we hate lawyers who do this and justify themselves in this way? It is not just because of the bad social consequences that "attorneyphobes" can list ad nauseam. I think we dislike these lawyers because they cover plain greed with grand social purpose, giving both motives a bad name. Ironically, this is the very thing that Boatright fears $\mathrm{MgM}$ will do: give managers a way to cover guile-driven self-interest with a cloak of good intentions. It is enough to drive one to virtue theory.

\section{End Digression}

Before the digression I argued that the passion of self-interest could interfere with the business role of wealth creation as much as our passions of care, loyalty, and fairness. How should these passions be handled in business? One strategy is to design organizations that align self-interest, friendship, group loyalty, and fairness. But this presupposes the legitimacy of some form of $\mathrm{MgM}$, since managers will have to integrate these factors in ways that do not merely serve themselves or their idiosyncratic interests. I don't see any market solution for this problem.

Another problem with MkM is that roles, as opposed to rules, are useful just because they are open-ended. For example, the roles of CFOs expanded with the appearance of derivatives and stockholder lawsuits. Companies did not have to reorganize to address these new issues. They had roles that were ready to absorb them. However, sometimes new roles emerge, as did the role of corporate ethics officer. This new role then reshapes other corporate roles such as HR, Purchasing, and Sales. Perhaps the most dramatic change in corporate roles in the past thirty years is that of the CEO. This has increasingly become a more public, political, and social role.

The next question is the famous, So what? Let's suppose that Boatright is right about the need for MkM because of the failure of MgM. How do we create a moral market place? Or, if we assume that we already have a moral marketplace (does anyone believe this?) how do we keep it moral? If there is nothing we can do to influence MkM, then it is at best a fun exercise in conceptual analysis-not that there is anything wrong with that. In discussing the origins and influences on markets, I confine myself first to the West, then the US.

There is good reason to believe that organizations play a major role in constructing and influencing the rules and roles that shape markets. These organizations can be from the business, government, or the non-profit sectors. A 
thousand years ago, the church influenced the shape of markets. As the power of the church waned, government's grew. This was not an accidental shift. Douglass North argues that the growth of trade between 1000 C.E. and 1600 C.E. made those in business realize the importance of a secure social-economic infrastructure. ${ }^{6}$ To reduce transaction costs, business needed, among other things, defined and enforced property rights, standards for measurement, and a stable monetary system. ${ }^{7}$ Businesses and guilds urged and paid for the then minimal governments to provide this infrastructure. Given the way business views government now, we can see this is yet another instantiation of Mary Wollstonecraft Shelley's Frankenstein.

As we begin the third millennium, that is, now, business has taken back some of the control it ceded to government, at least in the U.S. Some business organizations act as if government did not exist, such as Microsoft. Microsoft hired its first lobbyist in Washington DC in 1995. Most other businesses work with government to advance their own interest (Boeing, companies in the steel industry, the textile industry, the sugar industry...). Enlisting government as a partner to promote marketing and financial goals can be very successful, as the Cato Institute usefully reminds us. ${ }^{8}$

Business has not disposed of its Frankenstein, also known as government, and business is still unpleasantly surprised, on occasion, by what government does. That said, business is coming to understand the levers and wheels of government better and better. A large part of this understanding is grounded on public choice theory, which characterizes governments as markets and political candidates as entrepreneurs who sell bundles of political goods in exchange for votes. Sometimes business moves governmental levers and wheels directly, for example, when regulatory agencies are headed by individuals who used to run regulated businesses, and sometimes by remote control, by funding PACs that engage in media campaigns on behalf of pro-business candidates. Of course, not all so-called pro-business policies improve the climate for all business, since what benefits one industry can harm another. Still, the influence remains.

If what I have said is true, or at least true enough, then the golf clubs that can get the ball of MkM off the $t i$ of wishful thinking are business organizations, and that, as Julie Andrews says, brings us back to do. Or, more appropriately, the dough. Dough is supposedly the object of all business organizations, and changing that basic fact is something for which Boatright has little hope. If he is right, $\mathrm{MkM}$ is in jeopardy because $\mathrm{MgM}$ is the path to MkM.

Have I made any progress in following Boatright's argument back to the beginning? I think so, but it will not be apparent until we look at Dunfee's address and weave the insights of their talks together. ${ }^{9}$ 
In the abstract to his address "The Marketplace of Morality: First Steps Toward a Theory of Moral Choice," 10 Thomas Dunfee states:

A marketplace of morality (MOM) is a place where individuals act under the influence of their moral desires. A MOM produces an output representing the aggregate acted-upon moral preferences of its participants. Individual behavior is influenced by POPs, or passions of propriety. People implement POP preferences when they buy stock, purchase goods and services, choose jobs and so on.

Like John Boatright, Thomas Dunfee places his hopes on markets. This is not surprising. Markets are the dominant ideology of the day, and for good reason. It is widely accepted that the failure of the USSR and its satellites was not merely a failure of those particular countries, but the failure of the ideology of centrally planned economies. This failure, in turn, is supposed to justify capitalism, since that is the only other alternative. While this may be true, there are many different ways to set up capitalism. So many, I think, that to say that capitalism has triumphed tells us very little about how societies will look at the ground level. This is a topic I cannot pursue here.

I do not have the time to deal with Dunfee's presidential address in the detail I would like. I will focus on his main thesis, which is that MOM emerges as a result of people expressing POPs. We express our POPs in many different ways. Our choice of stock, shoes, flowers, employment, political candidates, indeed almost any decision can reflect our POPs that will feed into MOM. A very appealing feature of MOM is that she does not care whether her inputs come from profit, non-profit, political, or legal sectors. MOM wants them all.

Dunfee asks whether we can price our POPs vis-à-vis each other, within a person and across persons. This is a difficult project for which he does not hold much hope. Independently of this problem however, he says, MOM reflects the POPs of the inputs, if only we know how to read it. Dunfee does not speculate how we could read MOM, a task that is at least as daunting trying to price POPs. But assuming we could read it, there is another, deeper problem. Why should we trust MOM?

What MOM says will tell us as much about her system of processing her inputs as the inputs themselves. By looking at MOM, I don't see anyway to tease these apart. But, even assuming we could overcome this obstacle, and we could take a good look at how MOM processes her inputs, is there a processing system that will actually represent the POPs of its constituents? Kenneth Arrow's voting paradox suggest it is logically impossible to devise such a system. Arrows paradoxes appear when as few as three people vote to ordinally rank three candidates. ${ }^{11}$ If we cannot create a processing system that will reliably reflect preference inputs for simple, ideal conditions, how can we hope to create one so for something like MOM that includes, as we noted above, inputs from profit, non-profit, political, and legal sectors: literally trillions of decisions of vastly different kinds. 
Boatright's hope that we can influence markets in order to change organizations and Dunfee's hope that we can read from markets the moral judgments of decision makers seems misplaced. What is left?

In the late 1990s, Dr. Georgia Sadler wanted to educate African-American women in San Diego about breast cancer. Her goals were to encourage selfexamination and to encourage them to seek medical help if they found suspicious lumps. She started by going to churches, but only about ten percent of the people would stay after church for the information sessions, and most of them already knew about the issues - they just wanted to learn more. Dr. Sadler decided to go to beauty salons. Successful stylists are generally good communicators. Women can spend two, four, even eight hours in a salon for complicated braids. There is generally a trusting relationship between stylists and their clients. It is a place where, let me apologize in advance, women can let their hair down.

Dr. Sadler did not go into the salons herself. Instead, she decided to seek and train hairdressers. She found participants who were willing to learn about breast cancer and to talk about the subject with their clients. She also hired a folklorist to help them with their storytelling skills. Dr. Sadler did not go to federal or state government to seek large grants and she did not use media. She cobbled together some money from a few small grants. Yet, she found an entry point that worked.

Beyond the unusual educational venue, two points struck me about this case: first, Dr. Sadler did not have to persuade the stylists to convey this information, and, second, the stylists did not need to convince their clients that this was an important subject. The information and stories were compelling in themselves. How often is this true of our stories in business ethics?

In what follows, I use the Sadler case along with insights from Boatright and Dunfee to explain and justify my plea for institutions and action.

My plea for institutions is a call for the study of social institutions and how they integrate different levels of analysis pertinent to business ethics. I believe that this will enrich our scholarship and our discussions about business ethics.

I suggest the following levels as a starting place:

1. Individuals

2. Families and small intimate groups (groups of individuals)

3. Organizations

4. Large groups (groups of groups)

5. Markets

6. Social institutions

7. Social institutional frameworks

As Richard De George has noted, issues often intersect with different levels. Dr. Sadler was an individual who wanted to reach other individuals to help them lead healthier, better lives. She went to the third level of analysis, namely churches, to reach these individuals. When that failed, she reached out to small 
businesses, beauty salons, which are at levels 2 and 3 . If she were to reach out to make this a national campaign, she would have to deal with levels 4, 5, 6, and 7 . If her project were successful at the national level, the number of African-American women in the health care system would go up and their deaths from breast cancer would go down. This would be registered by MOM. But we could not read MOM accurately unless we could trace the inputs from Dr. Sadler, and all the others who worked on the project, to these results.

While I was highly critical of MOM, I did so only to bring out that MOM cannot do all Dunfee hopes. However, if we examine the other levels of analysis, MOM is an ineliminable part of the study of business ethics. We find the same kind of help in Boatright's focus on using markets to change organizations. Boatright's address can help us understand the value of Dr. Sadler's project in a new way. Sadler is an individual who is changing the demand on medical markets by educating women about self-examination. This, in turn, can change the organizations in the medical delivery sector. But here is the rub, and where I part company with Boatright. If the organizations in the medical delivery market have new demands, these demands are likely to affect the larger insurance and political markets in which these organizations work, also known as MOM. Individuals and organizations play a crucial role in changing markets.

What happened to the hedgehog and the fox? The focus on markets is a hedgehog view, especially if there is very little talk of the other levels of analysis. In my text, Business Institutions and Ethics, ${ }^{12}$ I was a hedgehog about organizations, seeing them as the Big Answer to most problems business ethics. I talked about individuals and markets, but mainly in terms of how they influenced organizations. What I did not talk about, and am just beginning to appreciate, is the importance of the second level of analysis-family and friends-for understanding and changing business behavior.

I said earlier that we needed a robust theory of ethics before we could successfully pursue our objective to make business organizations more ethical. I am now about to make a stab at suggesting a necessary condition for such a theory. A robust theory of business ethics is one that can account for all seven levels of analysis. There almost certainly will be more than one coherent theory that fits these levels together in different cultures, nations, organizations, and families. The important point is that a robust theory is not necessarily a unique theory.

My plea for action is a direct response to Brother Leo's address. We should nurture our relationship with SIM and the Academy itself. But I also propose we establish relationships with Ethics Officers Association (EOA). The EOA has over eight hundred members, who represent some of the largest companies in the world. Ed Petrie, their executive director is interested in joint projects.

I also suggest that we establish a relationship with the AACSB, the accrediting body of collegiate schools of business, to improve the quality of ethics teaching in member schools. As we know, some schools take seriously their mandate to teach business ethics. Many do not. Business ethics classes are given to faculty members who have no experience in the area. I have no specific proposal in mind. 
However, I do suggest a tactic. Deepen our relationships with SIM, develop a relationship with the EOA, and then, as a team, approach the AACSB to discuss this problem. From Boatright's point of view, we would influence a market maker, the AACSB. From my point of view, it is a strategy that pays attention to different levels of analysis. From Dunfee's point of view, we would use our POPs to influence our MOMs.

Who else should we seek to join with? Well, "Who are our hairdressers?" My suggestion that we look to the AACSB and the EOA is obvious, I think. Just as going to churches was obvious to Dr. Sadler. We need to keep our minds and eyes open for effective connection points that are not in the mainstream.

Lastly, I address the issue of undue influence. "Who are we to suggest that organizations ought to act in some ways and not others?" There are at least two responses to this. First, so what? We are just one among many voices seeking to be heard. That is the nature of a representative democracy. Second, SBE is fox like. We originally formed as a group of people with lots of ideas, looking for place to voice them. We did not come together to find the Big Answer. And that is why SBE is not subject to the hedgehog in fox's clothing problem, what I called the zoological paradox. Even if it is true that every individual faces this paradox, organizations that keep channels open for diverse voices, and are based on robust theories, can avoid it.

In closing, I would like to thank Brother Leo Ryan, John Boatright, and Thomas Dunfee for their inspiring addresses. I would also like to thank Dr. Sadler, whose example gave me the idea for the talk in first place. Finally, I would like to thank the members of SBE for welcoming me into this group more than twenty years ago, and for electing me to the positions that have culminated in this address.

\section{Notes}

11995 Business Ethics Quarterly 5:4.

2 This is the current mission statement, but the elements are very similar to the mission in 1994.

${ }^{3}$ Our success as a forum for ideas actually works against promoting organizational change, since the forum invites and enjoys and controversy. Selling controversy to organizations is difficult, to put it mildly.

${ }^{4}$ Berlin, Isaiah. 1978. Russian Thinkers. New York: Viking.

${ }^{5}$ Business Ethics Quarterly 1999 9:4 583-591

${ }^{6}$ North, Douglass. R. 1991. "Institutions.” Journal of Economic Perspectives 5:1.

7 Ibid.

8 The Cato Institute is a libertarian think-tank that, among other things, keeps track of how government transfers wealth to business <http://www.cato.org/>.

9 You may be wondering what happened to the seventh note, la. I simply could not find a way to make it work. I am not in bad company, as Rodgers and Hammerstein had trouble with it, too. They described $l a$ as the note that follows so.

${ }^{10}$ Business Ethics Quarterly 8:1 (1998).

11 Arrow, Kenneth. 1963/1951. Social Choice and Individual Values. New York: John Wiley and Sons.

12 Dienhart, John. 1999. New York: Oxford University Press. 